\title{
広島逓信診療所の建築について \\ A STUDY ON THE ARCHITECTURAL DESIGN OF HIROSHIMA POST HOSPITAL
}

\author{
李 明*, 石丸 紀 興** \\ Li MING and Norioki ISHIMARU
}

\begin{abstract}
This paper focuses on Mamoru Yamada's architectural design of Hiroshima Post Hospital. As the first series of his design for the hospital, it represented the latest hospital layout including a definite design on the zoning and a movable outline function. Especially when we refer to the layout of consultation rooms. With the internal medicine room as the center, the surgery, ophthalmology, and x-ray room were allocated according to the American 'History Corridor' design. With the sunroof, the technique of catching the sunlight had been used. In order to get enough sunlight for the corridor, in between the border of each room, parapet is used as the upper part of the roof as well as the well-ventilated window. This type of architectural design concept marks the beginning of the modern rationalistic architectural in the modern Japan. In addition, it has a profound impact on the latest rationalistic work such as the architectural design of Tokyo Post Hospital.
\end{abstract}

Keywords: Hiroshima Post Hospital, Mamoru YAMADA, Tokyo Post Hospital , Osaka Post Hospital, modern segregated architecture 広島聥信診療所、山田守、東京聥信病院、大阪聥信病院、近代合理主義建築

\section{1.はじめに}

聥信省の建築家として䢖信省在任中数多くの局舎建築を設計した 山田守であるが、通常の局舎建築とは趣を異にする病院建築の設計 はその数が少ない。これまで彼の設計と確認できるのは広息聥信診 療所 ${ }^{1}$ (昭和 10 年 11 月竣工)、東京聥信病院(昭和 12 年 10 月竣工)、 大阪进信病院(昭和 13 年 10 月竣工)の 3 件のみである（以下これら の 3 病院を莪信病院と称する)。中でも東京违信病院は日本近代にお ける合理主義建築 2 代表作として特筆されている゙だけでなく、山 田守の戦後においての数多くの病院建築 4 に手掛ける契機になった ものとしても高く評価され、大阪违信病院はその「写し設計」とし て評価されている5。それに対し、東京莪信病院より 2 年前に建てら れた広島魀信診療所は彼の最初の病院建築と言われながらも6、これ まではあまり注目されていなかった建築であり、ほとんど研究7され ていない。

広島遁信診療所は山田守の最初の病院建築として、彼の諸活動と 病院建築との関わりを考える上で重要な意味を持つ建築であるだけ でなく、山田守の 1930 年代初期の作品として彼の初期の合理主義建 築を語る上でも興味深い建物と思われる。現在では、被爆後玄関棟 が取り壊され、元の外来診療棟のみが残っているか、新築当時の姿 はほほ保存されており、周囲の建物と共に良好な都市環境を作り出
している。しかし現地では市街地再開発にあたってそれらに対する 正確な情報を求めており、本稿はこのような動きに対応するものと しても重要である。

本稿は、広島违信診療所に関する諸文献と調査 ${ }^{8}$ を通して、その沿 革、設計の特徵について検討・評価し、また東京・大阪逓信病院と の比較考察を通じて、山田守の用信病院設計活動における広島聥信 診療所の位置付けを明らかにすることにより、山田守の近代合理主 義代表作である東京莪信病院設計活動との関連について考察しよう とするものである。

山田守については、その作品集 ${ }^{9} や 、$ 向井覚による身近にあって始 めて可能な伝記的労作など ${ }^{10}$ があり、莪信病院建築についても、特 に東京聥信病院建築については、既に多く論じられており一定の史 的評価も定まっている11。本稿はこれらにも多くを負っている。

\section{2. 広島进信祄㙩所の治革及ひ建築概要 $2-1$.沿革概要 12}

広島违信診療所は大正 11 年に初めて共済組合による尃属の医療 機関として設立され、大正 11 年 4 月、木造にて広島市西地方町 134 番地に新築されたがその設計者は不明である。その後、聥信診療所 設置の規定化によって、莪信局内職員及びその家族の偒疾、疾病の
*広島大学大学院工学研究科 博士課程後期 - 工修

** 広島大学工学部建築計画学 教授・工博 
診療治療をする目的をもって、広島聥信診療所は昭和 10 年 11 月 27 日、 $\mathrm{BC}$ 造にて広島市中区基町 6 番地（現在の中区東白島町 19 番 16 号) に新築された。その設計者が山田守であり、本稿の考察対象に なる広島聥信診療所（以下「診䍌所」と略す場合がある）である。 診嗦所は昭和 9 年 11 月 15 日に起工式、翌年の昭和 10 年 11 月 27 日に工事完成、同年 12 月 20 日落成式、同年 12 月 22 日開業式が挙 行された。総経貫は 131,876 円であった。運営に当たっては、莪信 部内職員共済組合診境所規定として、所長、医員、書記、薬剤長、 技術員、看護婦などの職員を置いた。広島逓信局長は前項職員のほ

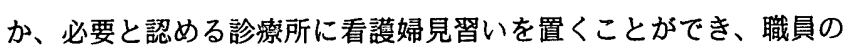
うちより各一名を限り医長、事務長、薬剈長、看櫒婦長を命じるこ とができた。昭和 12 年 2 月 1 日、広島聥信診曂所規定廃止、共済組 合診漂所全部を国営に移管した。ただ、薬局は共済組合に残した。 昭和 15 年 7 月 12 日、診療所の各科には科長が配置され、内科、外 科、眼科、耳界咽做科、小児科、歯科の 6 診療科となり、それそれれ に科長を配置した。昭和 17 年 2 月 10 日診㙩所を広島聥信辟総務部 の一院として、広島聥信局総務部聥信病院と改称。昭和 17 年 11 月 1 日広島聥信局広島聥信病院となり、産婦人科を設置した。当時の 在籍職員は、医師 10 人、看櫒婦 20 人、その他 17 人、合計 47 人で あった。

昭和 20 年 8 月 6 日被爆。被爆したため鉄筋コンクリート造の本体 及びレントゲン装置を残し、悹、屝その他内部諸設備品の殆どが破 壊锛失した。特に二階は産婦人科、雪科診療室を除く入院病室、食 堂、浴室、物置、宿直室、応接室等火災のため壊滅状態になった。 昭和 22 年 3 月より本格的に復旧工事に着手、遂時年次を追って整備 され、昭和 55 年 12 月総合病院となり現在に至る。

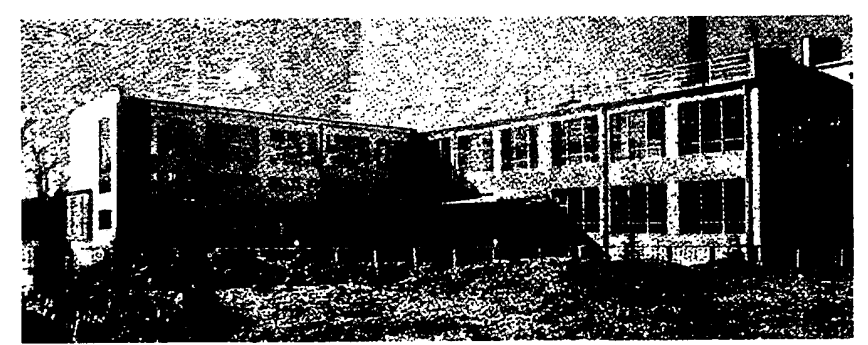

図 1 北側からの外観。左側が病棟、右側が玄関を跓いた事務棟（1935 年）
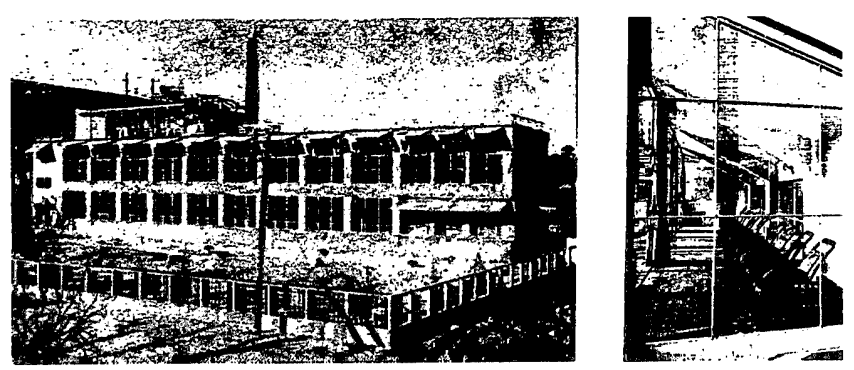

图 2 病棟南側の外観。1 階か診察室、2 階が病室、3 階は日光室 (1935 年)

\section{2-2.建筑概要}

広島莪信診療所の建築に関わる原資料は原爆によって全て失われ ているので、設計図面や当時の施工技術、病院としての設備的なも のを検証することはできない。被爆後の木造建築で復興された建築 の資料は中国郵政局建築部に保存されている。当時の貫重な写真集 も少量ではあるが同所に現存されている。その他、山田守の作品集 に紹介されている写真と図面がある ${ }^{13}$ 。以下、これらの資料と現状
とを比較しながら、建物について検討する。

新築当時の㟝療所は鉄筋コンクリート造、地下 1 階・地上 2 階・ 一部 3 階建て、敷地面積は 746.5 坪、建築面積は 487 坪、病室は 12 室、ベット数 30 であり、病院としては比較的小規模なものであった 14。当時の設計図面は残っていないか、「合衆国戦略爆杽調査団の報 告」15によると次のような特幑が認められる。(1)構造 : 鉄筋コンク リート造、(2)屋根 : 鉄筋コンクリート梁とスラプ、(3)間仕切り : ラ スと漆喰（木のラス）、(4)壁 : 8.5 インチ鉄筋コンクリート、大開口 空、(5)休 : 鉄筋コンクリート梁とスラプ、6)空及びドア一枠 : 鋼鉄、 ○天井はコンクリートの上に漆喰塗、などである。

ブロック・プランは玄関を中心にして南側が診療と病棟、北側か事 務棟になり、1 階は診療部門と事務部門の西側が廊下で結はれ中庭 式のブロックになっていた。なお、玄関を東面にさせ、その前面に は三角形の空地を設けて患者を玄関に導いている。診療棟は 1 階か 診察室、2 階が病室、一部 3 階は日光浴室となっていた。そして、 診療棟は 1 階が外科、内科、2 階は夝婦人科、眼科、小児科となっ ている。立面は桁行きスパンいっぱいに空をあけたデザインであり、 外壁の角部、庇の角、屋上手すりの角等は曲面になっている。なお、 サッシが外壁に近くつけられているなど、軽快で明るく威圧感を与 えない親しみ易い表現になっている。

被爆によって大きな被害を受けたか、その後の復旧整備によって 診療所はその規模を拡大し、現在は、玄関棟が取り壊されていて、 元の外来診療棟か、新築当時の姿を継承する形で保存されている状 態である。

\section{3 。 山田守における広島聥信診療所の設計経緯 3-1.山田守と违信病院建築}

逓信省では部内固有の総合病院が必要であるとの観点より、大正 末期から昭和初期にかけて前後 10 回、大蔵省に建設費の予算要求を 行ったがすべて認められなかった。昭和 8 年、当時の聥信大臣南弘 は専属病院の必要を認め、民間の有力者や新聞通信社に呼びかけた。 そして民間から募金によって病院を建設し、これを国に寄付しよう との議がまとまった。この案は財政界の賛同を得て、昭和 9 年の初 に、東京及び大阪に魀信病院建設後援会が結成された ${ }^{16}$ 。それに伴 って各地方の追信診療所も、その後の莪信局内職員及びその家族の 傷疾、疾病の診療治療をする目的を持って診療所を拡大して新築移 転し始め、迎信病院の建築は聥信省経理局営繒課 ${ }^{17}$ が担当した。

山田守は大正 9 年に東京帝国大学工学部建築学科を卒業し、同年 聥信省経理局営繥課に奉職し、昭和 15 年には営繥課長となり、昭和 20 年の退官まで数多くの局舎建築を設計した。しかし通常の局舎建 築とは趣を異にする病院建築の設計はその数が少なく、これまで山 田の設計と確認できるのは、広島聥信診療所（昭和 10 年 11 月 27 日竣工)、東京莪信病院(昭和 12 年 10 月竣工)、大阪逓信病院(昭和 13 年 10 月 3 日竣工)の 3 件のみである。これらはいずれも 1930 年 代の作品として、山田の合理主義建築活動を語る上で欠くことので きない建築である。1930 年代の山田守は欧米への出張18、用信省の 合理化経済化を求める建築設計方針 ${ }^{19}$ を契機として近代合理主義建 築を目指して活発に建築活動を展開した ${ }^{20}$ 。山田守は後になって「外 遊中ヨーロッパでも、アメリカでも、お医者さんの友達が多かった ものですから、ベルリンとかフランクフルト・アム・マインの新し 
い病院とか、ニューヨークのメディカルセンターとかいろいろ見て きました。そういったことで多少病院建築にも興味を持っていたの ですが、州ってしばらくすると派信病院を造ることになりました。」 21 と述べている。浜口隆一は「出張を通して建築の科学性・経済性 に対して、鋭く意識させられ、帰朝した山田守が自分の仕事といて 取り組んだのか、、莪信病院である」 ${ }^{22}$ と、山田守の出張と連信病院 建築の関わりについて指摘している。なお、村松貞次郎・堀勇良は 1930 年代の山田守について「合理主義を推進した戦前莪信省の旗 頭」と評価し $23 、$ 薬師寺厚は「…この時期は、帰朝後、終戦を期と して聥信省を退官されるまでの間で、東京莪信病院をピークとして、 山田さんの手になる莪信建築秀作が続々誕生した時代である。」 ${ }^{24}$ 述へててるように、1930 年代は山田守にとって合理主義建築の活動 期であり、東京莪信病院はその時期の代表作として高く評価される こととなった。

表 1 広島违信祄療所と東京・大阪违信病院の建設関連比較表

\begin{tabular}{|c|c|c|c|}
\hline 内容 & 広島聥信病院 & 東京通信病院 & 大阪通信病院 \\
\hline 設計者 & 山田守 & 山田守 & 山田守 \\
\hline 設言中時期 & 不詳 & $\begin{array}{l}\text { 昭和 } 9 \text { 年 } 6 \text { 月 昭和 } 10 \\
\text { 年 } 12 \text { 月に完了 }\end{array}$ & 不群 \\
\hline 着工時期 & 昭和 9 年 11 月 15 日 & 昭和 11 年1月 10 日 & 昭和 12 年 6 月18日 \\
\hline 竣工時期 & 昭和 10 年 11 月27日 & 昭和 12 年 6 月 6 日 & 昭和 13 年 10 月 3 日 \\
\hline 所在地 & $\begin{array}{l}\text { 広島市基町 } 6 \text { 番地 } \\
\text { (現在広島市中区東 } \\
\text { 白島町 19-16 }\end{array}$ & $\begin{array}{l}\text { 東京市趎町区富士見町 } \\
3 \text { 丁目元陸軍軍医学校 } \\
\text { 跡 }\end{array}$ & 大吸市 \\
\hline 構造 & 鉄筋コンクリート造 & 鉄筋コンクリート造 & 鉄筋コンクリート造 \\
\hline 規模 & $\begin{array}{l}2 \text { 陛 - 一部 } 3 \text { 階 } \\
\text { 地下 } 1 \text { 階 }\end{array}$ & 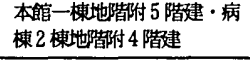 & $\begin{array}{l}\text { 地下附 } 4 \text { 階·一部 } 5 \\
\text { 階建 }\end{array}$ \\
\hline 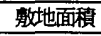 & 746.5 坪 & $4,461.00$ 坪 & 不詳 \\
\hline $\begin{array}{l}\text { 延面積 } \\
\end{array}$ & 487.00 坪 & $4,304.83$ 坪 & 2500 坪 \\
\hline 病室 & 12 室 & 大痌室 7 小病室 61 室 & 不詳 \\
\hline 病床 & 30 㕅 & 261 床（計画 400 床） & 200 (計画 250 床) \\
\hline 分科数 & 3 科 & 10 科 & 不詳 \\
\hline 工事費 & 131.876 円 & $1,053,234 \mathrm{PP}$ & 665,000 円 \\
\hline 製図 & 不群 & $\begin{array}{l}\text { 片山隆三、㓦川成美、羽石 } \\
\text { 渡、樚证男、守武充 }\end{array}$ & 羽石渡、都木荤福 \\
\hline 監督 & $\begin{array}{l}\text { 星野栄一、竹越新一、 } \\
\text { 杉凩 }\end{array}$ & 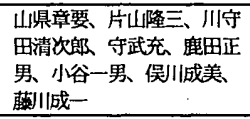 & $\begin{array}{l}\text { 土屋百三、川守田清 } \\
\text { 次郎、北村金弥 都 } \\
\text { 木孝福 }\end{array}$ \\
\hline 施行業者 & 坂本組 & $\begin{array}{l}\text { (株) 大會土木（現在の } \\
\text { 大成建教）等 }\end{array}$ & 松村組 \\
\hline
\end{tabular}

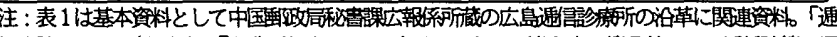

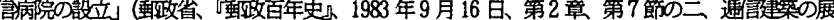

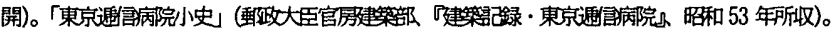

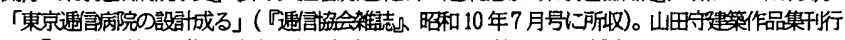
会、『山田守建㝝作品集々東海大学出版会、昭和42 年。等によって補完した。

\section{3-2.山田守にとって最初の病院建築}

山田守設計の 3 逓信病院はいずれも 1930 年代の作品であり、 3 病 院の着工時期の順序は広島逓信診療所一東京派信病院一大阪违信病 院になっているが、その設計時期については東京聥信病院の設計時 期以外は不明である。本節ではその設計時期の順序について検討す る作業を通じて、広島莪信診療所が山田守の最初の聥信病院建築で あることについて若干の確認と補足を行いたい。

先ず、3 病院の建設関連情報をまとめると表 1 のようにる。東 京莪信病院と大阪莪信病院を比べてみると、大阪䢖信病院の着工は 東京莪信病院設計より 1 年 4 ヶ月遅れていることか確認できる。そ の設計時期は不明であるが、東京莪信病院の設計が先行したことを 証明する有力な根拠として、「大阪派信病院は東京莪信病院のコピ 一のようなもので、自然熱意も足りなかったように思います。」 ${ }^{25}$ と の設計者本人である山田守の発言がある。ここで東京逓信病院は大 阪莪信病院より先行の設計であったことは確認できるだろう。なお、
表 1 によると、広島派信診療所が東京莪信病院より 2 年前に竣エし たことは確認できるか、、設計時期については東京莪信病院の昭和 9 年 6 月着手、昭和 10 年 12 月完成に対して、広島莪信診療所の設計 時期は不明となっている。これまでに莪信病院の設計時期の関連に ついては薬師寺厚などによる一連の聞き取りの調査記事がある。先

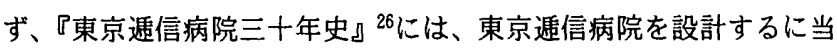
たって山田守には当局が買い漁った高さ $3 \sim 4$ 尺に及ぶ病院建築関 係の洋書が渡され、設計かできあがってからも当局との間で種々の 悶着があったという話しが幾䇢所かに書き記されている。その中に は「垍作としての広島聥信診療所(昭和10年)がある、‥」とい う話しも記載されているか、根拠は不明であった。次に、薬師寺厚 と片山隆三（元連信経理局営繥課技師・東京逓信病院設計に参加） の座談会での記録には「薬師寺 : 設計の段階までの話しだったら、 片山さんが一番よく分かっておられる。片山：ところか、当時はぺ いペいだったから、そんな曇の上の話しは分からない。具体的には、 山田さんがいよよ病院を作るんだそうだ、ということて…もち ろんあの時俚広島の病院、設計してありましたね。㝳 ${ }^{28}$ と記載され ている。この対話によると広島莪信診療所の設計は確かに東京莪信 病院設計より先行した設計だったことが大体判明できる。そして、 設計者山田守本人と薬師寺厚の対談の記録には「…薬師寺 : 荻䆶か ら次の大作の聥信病院に至る間におやりになったものでは、私か若 い時に感激したものに広島の迫信病院とか、神戸中央莪信局の養成 課…。山田：それから神戸の中央電話局もやりましたねa薬師寺 : 会島、熊本の貯金支局もその当時で…山山田：あれはちょっと後に なるかも知れませんね。‥」と記録されている29。ここで山田守は 広島莪信診療所の設計を最初の病院建築として認めていたこと、な お広島貯金支局らの設計についてもよく覚えていることなど、この 話しの確度が高いと考えられる。

東京莪信病院建設経緯に関しては、昭和 8 年 4 月莪信病院後援会設 立準備会発足、昭和 9 年 2 月東京莪信病院後援会発足となり、それ は広島莪信診療所の竣エよりほぼ 2 年前のことであったか、東京聥 信病院の設計完成時期（昭和 10 年 12 月）と広島聥信診療所の着工 時期（昭和 9 年 11 月 15 日）を比べてみると広島聥信㖣療所の着工 か 1 年 2 ケ程先行しており、建物の規模差は施工期に及び、竣工 時期は 1 年半程の差となっている。一方、東京违信病院の設計着手 は昭和 9 年 6 月で、広島聥信診療所の着エよりほぼ半年程度早いも のの、広島聥信診療所の設計かこの時期に同時に進行したとは到底 考えられず、既に終了していたと考えるのが妥当である。事実「東

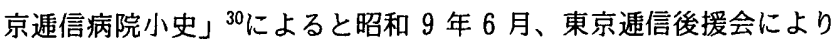
設計などの要請があってしばらくしてから経理局営䌜課が設計を担 当することになったわけであり、約 8 ケの設計準備期間をおいて、 昭和 10 年 3 月に敷地か購入され、9 ケ月後の同年 12 月に実施設計 お完了していると記載されている。すなわち、東京聥信病院の実施 設計は敷地が購入された昭和 10 年 3 月着手であり、これは広島莪信 䛦療所の施工着手（昭和 9 年 11 月 15 日着工）より 4 ケ月遅れてい ることが明らかになった。ここで東京聥信病院の設計は広島莪信診 療所の設計よりはるかに後のことと確認できるだろう。

以上により、山田守が関係した通信病院建築の設計順序をまとめ ると、広島聥信診療所一東京莪信病院一大阪莪信病院になる。この ように広島聥信診療所は、のちに東京聥信病院を初め数々の大病院 
を手挂けることになる山田か、この分野に初めて手を染めたものと して、山田守の逶信病院建築設計活動を考える上で興哧梁い建物で あると、考えられる。

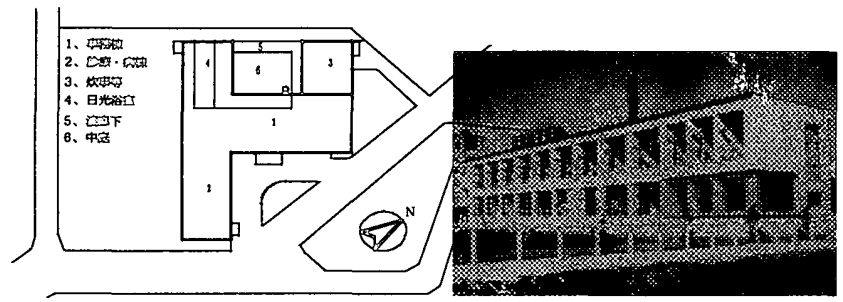

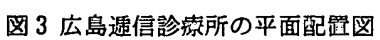

図 4 広島診療所の病槙の西南外観

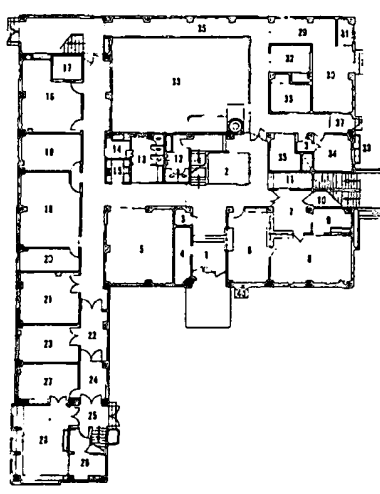

図 5 一階平面図

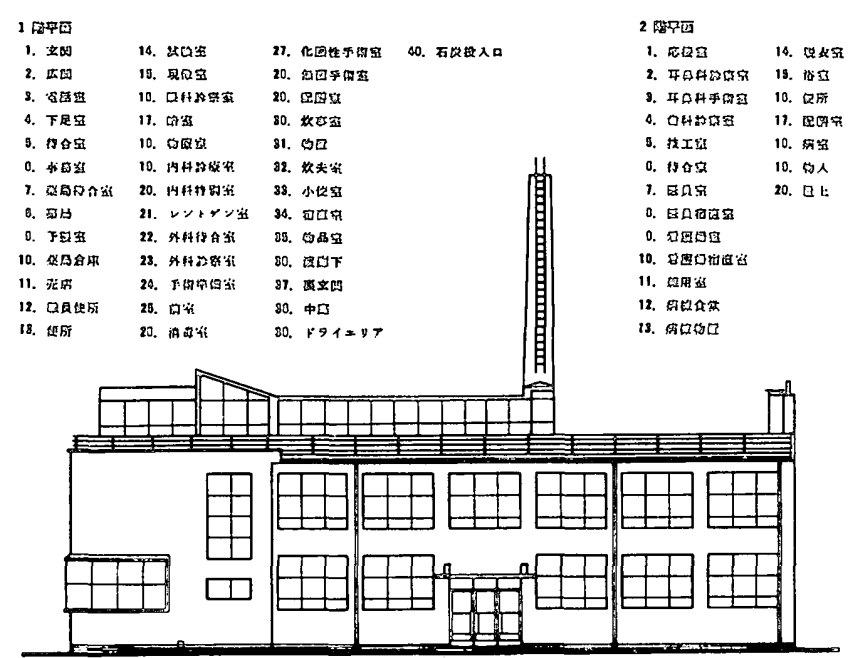

图 7 広島奥信診療所の亯立面図（正立面）

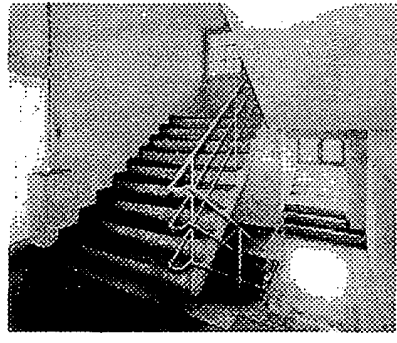

图 8 2 階陼段室 (西側)

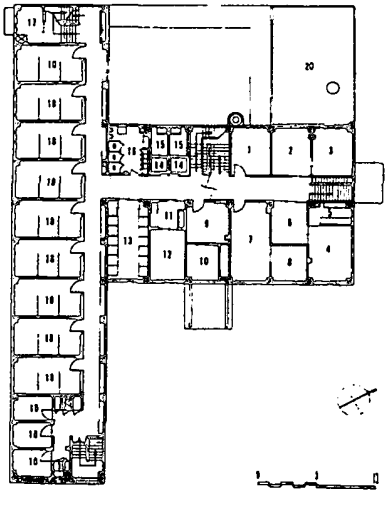

図 6 二階平面図

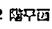

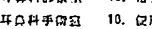
10.

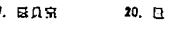

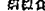

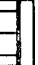 \\ 每}

ク・プランは玄関を中心にして南側が診療と病棟、北側が事務棟に なり、1 階は診療部門と事務部門の西側が廊下で結ばれ中庭式のフ ロックになって幾能を明確に区分し、玄関を東面にさせ、その前面 には三角形の空地を設けて患者を玄関に栵いている。当時の病院建 築の影地と建物との関係についての規則 ${ }^{31}$ の必然的結果とも考えら れるが、病院建築は外界との交涉が複雑であり、外来者、その他出 入りするものの種類が多いのに対しての、道路、広場、病院という 過渡空間の役割を考虑した設計者の設計手法でもあったと思われる 32。なお敫地の南側には広い空地を残し、将来の病院規模の抎張を 配虑した計画になっている33(図 3)。

病㫫は 1 階が診察室、2 階が病室、屋上には日光浴室が設けられ ている(図 5、6)。一階の診察室は南に向けて、内科を中心に外科、 眼科、レントゲン室などを配置し、その各室に浻って一方の共同の 待合室に接して所謂ヒストリーコリドアを配するアメリカ式のプラ ンになっている ${ }^{34}$ 。病棟の 1 階手前にある出入り口は外科専用のも ので、患者搬送の時にはわざわさ玄関から迂回せずに、直接この入 口を使用して手術室に運ぶことになっている。なお、廊下あたりの 空間を利用して緊急用の単独の待合室が設置されている。妻側の細 長い悹は階段室であり、採光が充分にとれるようになっている。階 段室はオープン型で廊下に接している(図 8)。病室は南に面してお り、空開口部は大きく採光は充分にとれている。夏日の際の日除け として病室の窓の上部にはオーニング (awning) が取り付けられて いる（図 2)。また、病室の通風を充分ならしめ、他方、廊下の採光 に資するため、廊下各室間の境には上部に欄間、下部には通風ガラ ス付採光空を設けている(図9)。特に屋上の日光浴室はディ・ルー ムの特化した部屋として造られ、日光浴室とティ・ルームを兼ねた 部屋になっている。1920〜30 年代の比較的規模の大きな病院建築で は廊下の突き当たりや建物の角部分に日光浴室（保養室、休息室と いう名称の場合もある）を設けた事例がある ${ }^{35}$ 。しかし、広島通信 診療所のように聥信局内職貝及びその家族の傷病、疾病の診療治療 を目的として建設された小規模の病院建築に日光浴室を配置し、さ らに日当たりがよい屋上の空間を利用して、日光浴と休稳空間の充 分な採光を考虑した設計手法は、当時としては極めて珍しかったと 言っても良いだろう ${ }^{36}$ 。また冷暖房装置を取り入れるなど当時とし ては画期的なものであった。

2 ）造形的特徵 : 造形的に見ると、ファサードは白い壁、大きな開 口、方立の細かいバランス上げ下げ空等から構成され、屋上にはカ ンティレバーのサンルームが設けられている。スパンは $3,600 \times$ 8,000 を基調として構成され、悹はスパンを 3 等分し、その大きさ は約 $W=2,600 \times 3,500$ となっている。なお、サッシ（サッシは鋼製 で部材寸法は細かい）が外壁に近くつけられ、診療所は軽快で明る く威圧感を与えない親しみ易い表現になっている。それらは当時の 傾向とも関わるが山田守設計の建築作品の特幑がよく見られる。ア メリカ合衆国戦略爆蒰調查団の報告害の中に『非常に大きい空』と いう表現を使っていることか、何か一般の建築の空よりも非常に大 きかった感覚でとらえられていたのではなかろうか。小原誠は「桁

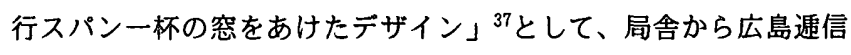
診療所、東京聥信病院への一連のデザイン的傾向をあげている。こ の診療所より少し前に建築された、広島聥信局 ${ }^{38}$ は彫りの深いどち らかといえば、重厚な感じの規模の大きい建築であるが、莪信診療 
所は非常に軽快で明るい感じのするスマートな建物となっている。 そして、診療棟の窓は $1 \cdot 2$ 階共、最下段は突き出し空、上段は上 げ下げバランス空になり、廊下の空は二重梁によって上下不同な意 匠を配慮されている(図 9)。外壁の角部、庇の角、屋上手すりの角 などは曲面になっている。ここで、山田守の 1920 年代においてよく 使っていた表現主義の色彩が濃い大きな曲面、アーチ模様の庇の工 夫等は姿を鿵している。バランスやプロポーションよりも輪郭の単， 純で明快な構成が追及され、平坦な壁と大きな開口部が主要なモチ 一フとなり、独立した装飾は一切除かれ、こうしてこの建物は明る く軽く陰毉を残さぬ空間とマッスから構成されている（図 1、2、4、 7 を参照)。そして、床仕上げはリノリュウム張りであり、天井釣り 照明器具は球形のグローブになっている。全館総ての器具は球形で 統一されていた。柱の角、梁の角、出入り口の周囲は小さな曲面に なっているなど、山田守がよく使う設計手法になっている。

以上のように、この建物は、山田守の初の病院建築としていくつ かの試みが見られ、新しい病院計画のあり方を示し、明確なソーニ ングと動線計画による機能的な平面計画となっている。なお、その 建築傾向には、単に合理性や経済性ということでは説明しきれない 意図が認められ、造形的な単純さもしくは軽快さと明るさか、この 建物には強く求められている ${ }^{39}$ 。

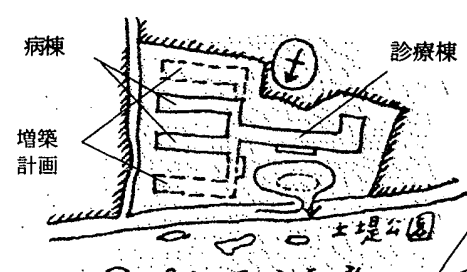

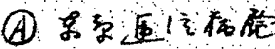

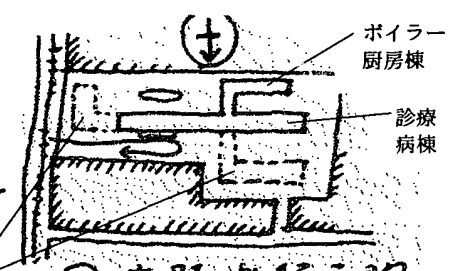

(B) AP\& $1 \varepsilon, 18$
図 10 東京聥信病院の平面配置図

図 11 大阪通信病院の平面配置図

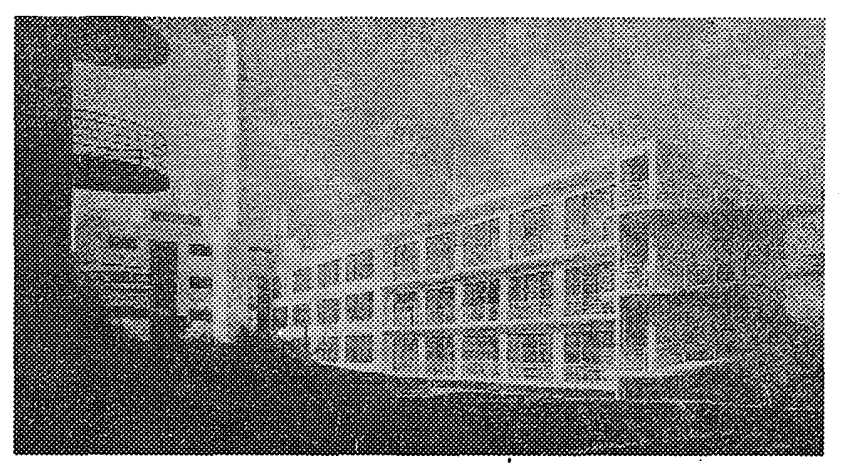

図 12 東京聥信病院病棟の南東外観（昭和 12 年）

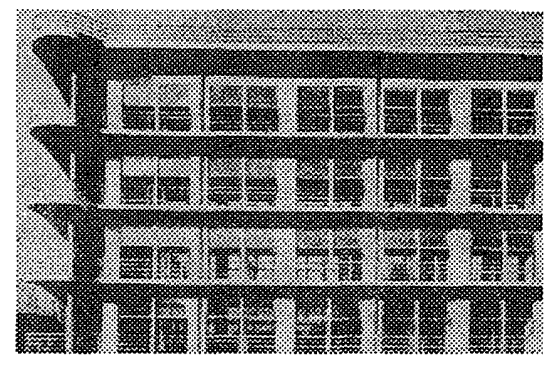

図 13 大阪迎信病院病棟の東南外観

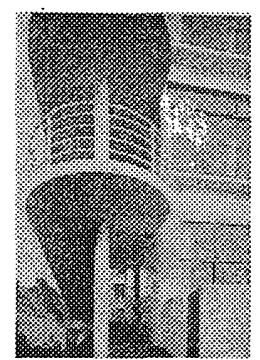

図 14 避難階段丸い踊り場

\section{5. 東京·大阪聥信病院建築との設計理念・手法の関連}

全般的にみると、規模の差はあるが、何れも直線・直角・平面と あいまって白一色を基調とし色彩をも単純化したスマートな形態か 眼に届く。3 病院の規模差が大きいため病院建築としての機能につ
いて全面的に比較を行うのは難しい。ここでは、主に 3 病院の設計 理念、形態の特徵を中心として若干の確認と比較考察を試みる ${ }^{40}$ 。

1) 工事費単位 : 表 1 を見ると、規模の差は大きいが、何れも鉄筋 コンクリート造建て、工事費は坪 200 円くらいで比較的安值であっ たことが認められる。当時、他の建築や電話局等が坪当たり 400 円 位であったといわれる。これらは山田守が建築の合理性・経済性に 对して、鋭く意識されていたことを裏付ける。ここで東京逓信病院 の合理化・経済化という合理主義的な特徵は広島聥信診療所におい で既に実現されていたと言ってもよいだろう。

2 ）配置計画：敷地の形態を見ると広島莪信診療所と東京莪信病院 はその規模と方位の差はあるがほぼ同じ形態になっている（図 3、 図 10)。東京莪信病院においては南北軸の中央廊下をもって東西軸 の各棟を直交連結するものであって、東側に南面して並列する病棟 （当初は 2 病棟、後になって 4 病棟になる）と西側に南面する診療 管理棟は整然とし、日照通風に最適の方位と間隔をもって配列され ている。玄関は北側に面し、その前面には広島违信診療所と同じ手 法でほぼ三角形のような空地を設けて道路、広場、建物玄関という 明快な過渡空間を与えられている ${ }^{41}$ 。そして病棟の 1 階手前にある 出入り口は外科専用のもので、患者搬送の時にはわざわさ玄関から 迂回せずに、直接この入口を使用するようになっている共通点が認 められる。大阪莪信病院の場合は図 11 のように、敷地はほほ長方形 のようなものであり、建物は診療棟と病棟は長方形の一本のブロッ クを東側の電車道路に垂直して配置され、南側のボイラー、厨房棟 は渡廊下で結ばれている。玄関を北側に面し（敷地の主要入口は東 側の電車道路に面している)、その前面には広い空地を残して将来の 病院規模の拡張を配虑した計画になっている ${ }^{42} 。 3$ 病院のブロック プランの構成は何れもデッサウのバウハウス校舎などと同じ手法の もので、機能が同じ室を重ね合わせて一つのブロック単位とし、こ うしてできる諸ブロック単位を有機的に連続していく。合理主義的 なプランニングの正統的な系譜に属するものと言えよう。しかし大 きな差異点として広島莪信診療所では診療棟と炊事室などの補足空 間を連結する渡廊下を利用して中庭を設ける手法になっているが、 東京违信病院と大阪莪信病院では、空気の停滞し、通風が悪く採光 上の欠点が多いなどの理由で中庭式ブロックを廃止している。しか しその廊下を設ける手法は東京遇信病院では病棟と病棟を結ぶ役割 を果たし、大阪派信病院では病棟・診療棟とボイラ一、局房棟を結 ぶ役割を果たしていた。

3 ) 病院建築としての科学的対底 : 3 病院は何れも病院建築の科学 的な機能の解决が認められる。日光浴室について、3 病院は何れも 屋上の空間を利用して単独に設けられている。広島聥信診療所では 日光浴室とティ・ルームを兼ねた部屋として設けられているか、そ の詳細については不詳である。東京・大阪逓信病院では患者の日光 浴の為には屋上日光浴室に紫外線透過ガラスを使用し、なお室外に ガラスクリーンを設け強風、裸身を他よりうかがわれる事を避ける ことになっている。このような設計手法は当時の日本の病院設計に 范いては極めて珍しかった。ここで、日当たりがよい屋上の空間を 利用して日光浴室を設ける設計手法は、広島聥信診療所に初めて採 用され、後の東京・大阪派信病院という時間の流れによってより洗 練され、具体化されたことを指摘しておきたい。病棟について、広 島逈信診療所は南西に向けて設けているか、東京聥信病院の病棟は 
できるだけ朝日（朝日の中には紫外線もあるからということを考虑 したと言われている)を満足させるために病室を東南に向けている。 また、東京・大阪逓信病院の大病室南側には回復期の患者の日光浴 に備えるため、3 段上げ下げ空を探用し、患者の寝台を直接露台に 引き出し得るように計画した。なお、露台は夏日の際の日除けとし ても有用なものであった(図 12、図 13)。広島莪信診療所の場合は、 夏日の際の日除けとして病室の葖の上部にオーニングを取り付ける ようになっていたのである（図 2)。そして、病棟には非常の際、患 者を担架に乗せ、迅速に移動できるよう、避難傾斜路を設けるなど の特徵が見られる。そして、手術空の空には防虫用網戸及び鎧形日 除をすべて設置しているが、広島聥信診療所については不詳である。 これらの特幑は東京、大阪聥信病院の方がより科学的に計画された ことを表している。なお、東京用信病院には病室の通風を充分にし、 他方、廊下の採光に資するため、廊下各室間の境には上部に欄間、 下部には通風ガラス付採光窓を設けるなどの特徵が見られるが、こ のような設計手法は既に広島派信診療所において実現されていたの である。

4) 造形的特徽 : 建築造形的に見るといずれも直線的あるいは直平 面が主要なエレメントになっている。しかし、ここで 1920 年代の曲 線の多用は影を潜めるが、建物や庇の角に小さな曲線が使われて、 病院の外観を感じる柔らか味を添えており、バウハウスなどの直線 的デザイン系譜のものとはやや異なって、山田守の設計の特徵とな

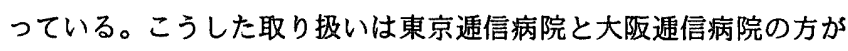
突き出した玄関の白い丸柱、避難階段の丸い踊り場(図 14)など曲面 部分がより眼に付くことが認められる。なお、白いタイルを内外と も同じよに使うのは病院建築としての特幑がよく認められる。3 つの病院のファサードは何れも白い壁、大きな開口、方立の細かい バランス上げ下け空等から構成され、屋上にはカンテイレバーのサ ンルームが設けられているなど、軽快で明るく威圧感を与えない親 しみ易い表現になっていることが認められる ${ }^{43} 。$

\section{6。まとめにかえて一山田守の莪信病院設計における広島聥信診療 所の位圆付け}

以上により、広島莪信診療所の建築を取り上げ、その沿革、設計 経緯、設計特徴について検討・評価し、また東京・大阪逓信病院と の設計理念・手法の関連について考察を試みた。

その結果、昭和 10 年 11 月に建てられた広島聥信診療所は、山田 守の最初の病院建築設計として、その規模が小さいか、建物の外観、 内部、その他における虚飾を廃し、単純明朗な形態となり、工費の 節減を計り、そして近代病院建築の複雑なる機能に対する科学的要 求を充足することに専心努力するなど、東京莪信病院の合理性を表 す多くの設計理念と内容は広島聥信診療所において既に初歩的に害 現されていたことが明らかになった。そして、山田守自身も後にな つて述へている44ように東京莪信病院と大阪逓信病院は設計理念と 形態はほほ同じカテゴリーのものであって、両者の差は規筫の大小 および敷地形状の制約によるのみであった。これらは、広島聥信診 療所一東京遁信病院一大阪莪信病院という時間的流れの中で、山田 守の合理主義病院建築の設計手法・内容は広島聥信診療所によって 初めて試行的に実現され、東京用信病院によってより洗練され、具 体化されたことを表明し、大阪莪信病院はこのような洗練された設
計手法の「写し設計」に当たることを表明する。また、「鬽信史話」 によると、東京逓信病院の設計は最初派信局外部の建築家に委託す る予定だったが経理局営繥課内部で “聥信省にも建築技師がいる。 それを自分たちに病院建築の経験がないからといって…” 45 という 強い反発の声が上かっった、という事情があった。そして荣師寺厚と 片山隆三の座談会での記録には「薬師寺 : 広島の郵政局の隣の病院 （当時、派信診療所と呼ばれたもの）は既に完成していました。片 山：黒い煙突のね。だから山田さんとしては自信を持っているわけ です。そこへ、上から、お前達は病院に関しては、ことに大きな病 院に関しては素人だと、で、三楽病院を設計された福田さんを連れ てきたものたから、山田さんが猛然と闘魂を燃やしたわけですね。 …」 ${ }^{46}$ と記載されている。それらは広島聥信診療所の設計は、山田 今が東京聥信病院を設計する契機となり、広島聥信診療所の設計を 通じて、東京聥信病院の設計に自信があったということを裏付ける。 ここで東京莪信病院という山田守の代表作の裹には彼の初めの病院 建築設計である広島聥信診療所があり、その果たした役割は大きか ったと言ってもよいであろう。村松貞次郎・堀勇良は「昭和 10 年の 広島聥信診療所を習作と考えれば、...」 ${ }^{47}$ として広島聥信診療所を 評価し、また、村松貞次郎は「…実際には小さなものではあったか 『広島聥信診療所』（昭和 9.11.15 10.11.27）という害績が山田に はある。そのあたり、あるいは山田一流の “呼吸”があったかもし れぬ。」48と述へているように、小規模ではあったが広島聥信診療所 の設計理念・内容は、後の東京・大阪莪信病院建築設計に大きな影 響を及ほしたと言ってもよいだろう。

つまり、広島莪信診療所は、(1)山田守にとっては最初の病院建筑 設計であること、(2)その規模が小さいが、単純明朗な形態となり、 新しい病院計画のあり方を示し、明確なソーニングと動線計画によ る機能的な平面計画になっている、などの特徵が認められる。特に、 診察室の配置にあたり、内科を中心に外科、眼科、レントゲン室な どを配置し、共同の待合室を設けるなどアメリカ式の合理的病院建 築のあり方の具現を試みた平面計画、日当たりがよい屋上の空間を 利用して日光浴と休想空間の充分な採光を考慮した設計手法、廊下 の採光に資するため、廊下各室間の境には上部に欄間、下部には通 風ガラス付採光空を設ける設計手法、桁行スパン一杯の空をあけた デザインなどは当時の日本では極めて先行的な設計手法であったこ と、(3)なおこのような設計理念と手法はのちの東京・大阪莪信病 院設計にも大きな役割を果たしたこと、などを評価したい。

謝辞 :

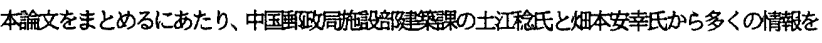

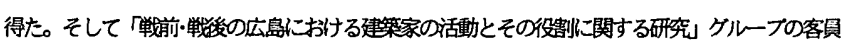

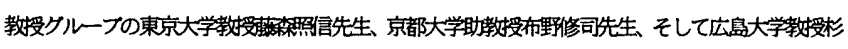

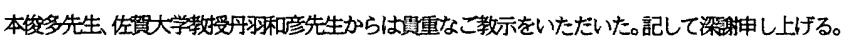

注 :

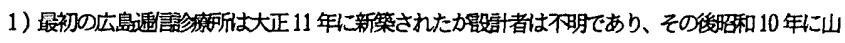

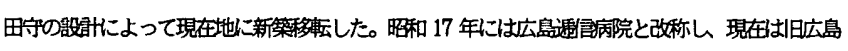

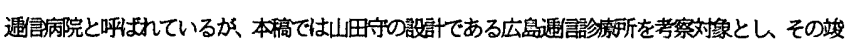

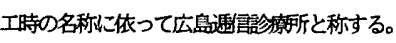




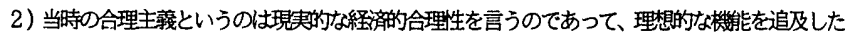

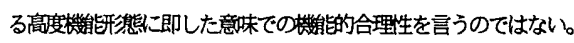

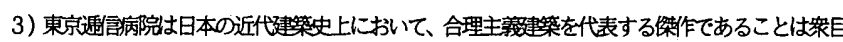

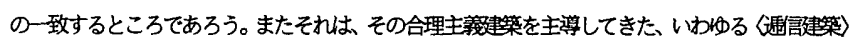

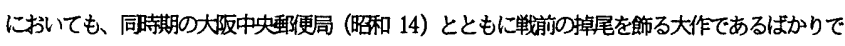
なく、山田守の作品中に挄ても東京中央電俍局（大正 14）と並んで届指の建筑でもある。合理

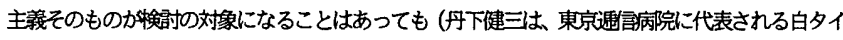

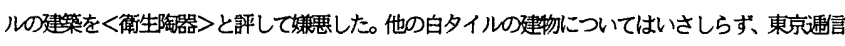
病院については、形状らの連想もさることなからら、その生理的性格までを言い当てている。丹下 健三は、豆磨に穴をあけた」たけの無邪気な合理主義たけてなく、白タイルに染みでている山田

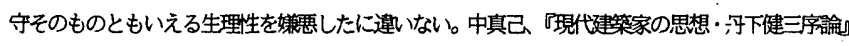
昭和 43 年)、合理主建筑作としての東京违病院の史的位置は不動であろう。また東京遇言

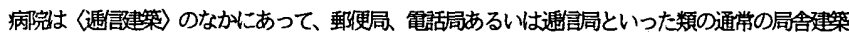
とは地を異にする病院建筑として、戦後の東宗覃生年金病院を初めとして数多くの病院建築を手か けることになる契機となった作品であるとも言われている。村松貞次郎・堀勇良は「東京遅䛸院 によって病院建筑家としての山田守か牲まれたのである。(材松貞次郎・堀勇良「日本近代建策史

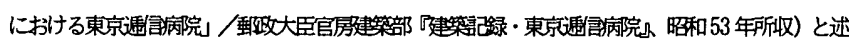
ヘ山田守を「病院建筑家」としても取り上げている。

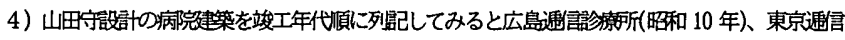

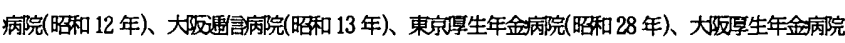
(昭和 29 年)、防衛宁東宗中央病院(昭和 30 年)、大阪市立大学医学咅附属病院(昭和31 年)、熊本

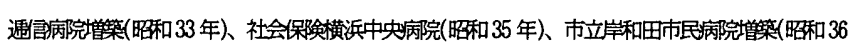

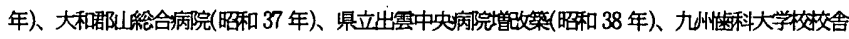

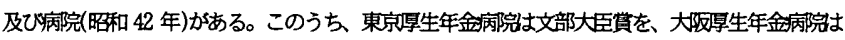

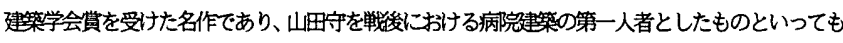
よいであろう。長㳊净水場 (昭和 32 年)、京都夕ワーヒル（昭和39年)、日本武道館 (昭和39 年)

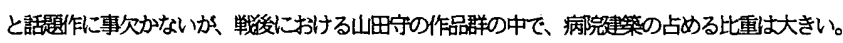
確かに村松貞次郎・堀勇良か述へるように山田守を「病院建築家」として評酒しても過言てはない と、筆者は考える。

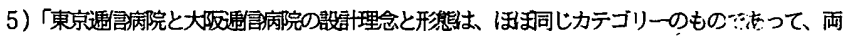

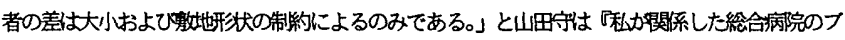

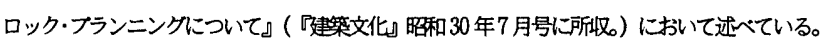

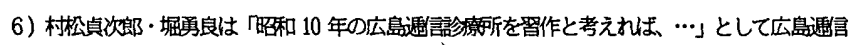

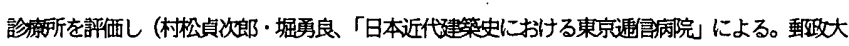

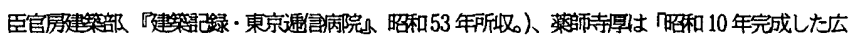

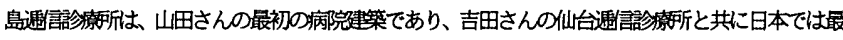

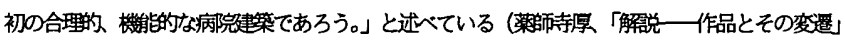

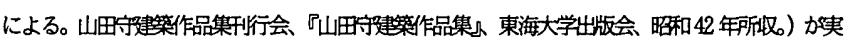
はその根拟の誁細蚏らかになっているとは言い難い。

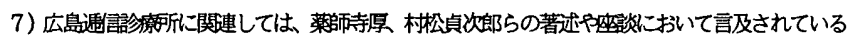
のか見られる程度である。その他、国际建第 12 巻1936年と山田守建築作品集刊行会、

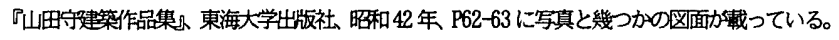

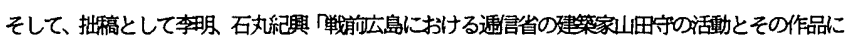

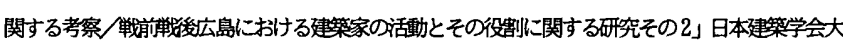

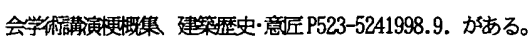

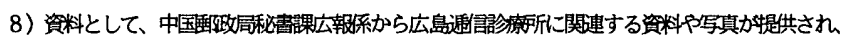

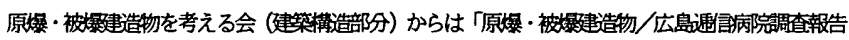
茟人1990年 4 月。方徒供された。第 2 等者は原爆・被㩧建造物を考える会の主幹であった。その

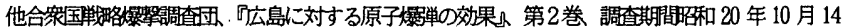

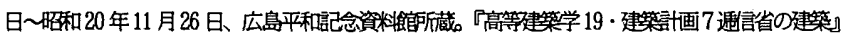

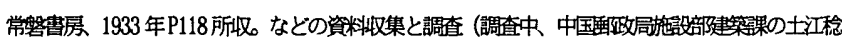
氏と烟本安幸氏から多くの情報を得た)、執筆なとはは第 1 篻者か行つた。

9) 山田守建符作品集干行会、P山田守建笑作品集、東海大学出版会、昭和 42 年。

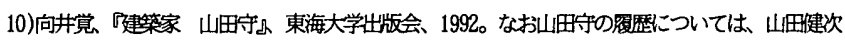

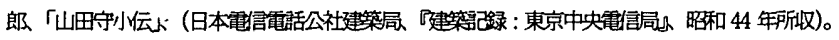
浜口隆一、建筑家山田守の思想とその作品」(『国祭建筑』昭和 29 年 2 月号所收)。

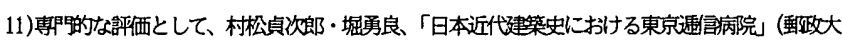

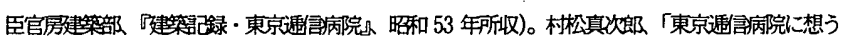

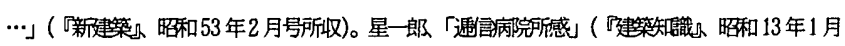

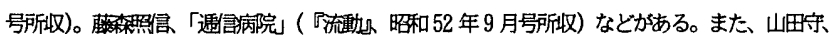
「私の関係した総合病院のフロック・フランニンクルンいて」（『建文化小昭和 30 年 7 月号所 収）上うな山田自身の分析もある。その他，通史の中て扱う近年の代表的なものでも、稆坦栄三

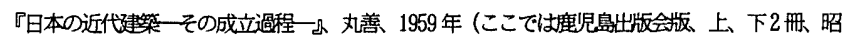

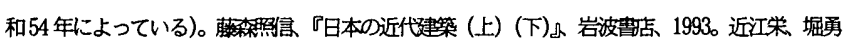

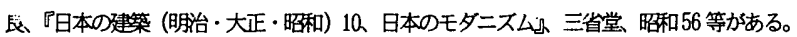

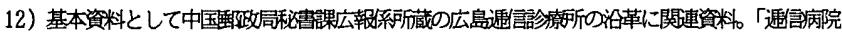

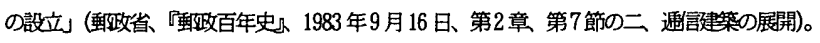
13)山田守建築作品集刊行会、『山田守建築作品集风東海大学出版会、昭和 42 年。

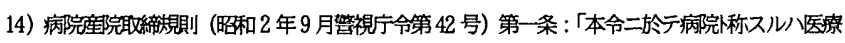
ノ目的习以テ患者 10 名以上习収容スへクモノ㯰上産院卜称スル人妊婦 10 名以上习収容スへ

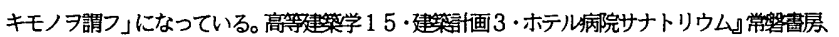

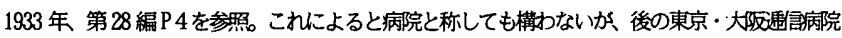
（表1を参照すること）なとにて比べるいななものであると言ってもよいたうう。

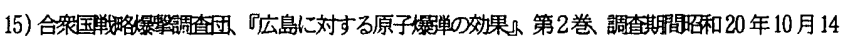
日〜沿和20年11月26日、広島平和記念資料馆所藏。

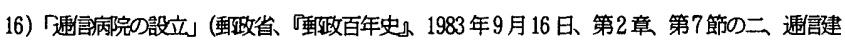
筑の展開)による。

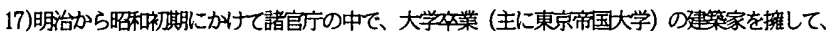

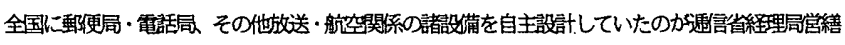

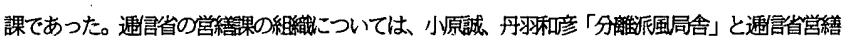
課の建筑 日本建学会計画系論文集第516号、P258。による詳しい研究がある。

18）山田守の 1930 年代の合理主新建辞動を考える拣 これまでは佊の昭和 4 年から昭和 5 年に

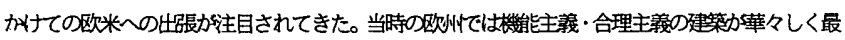
初の花を開いた頃でった。グロピス、コルヒュジエミース、アウト等の近代運動の指浖者た ちは住宅問題に一所㮣命に取り組んでいた。゙ウハウスの建等は 1926 年 27 年にはStuttgartの Weisenhof のSiedlung、29年にはコルビュジエの Garche の住宅、なと現代建築初期の代表秋作品 が出来ている。CIAM の第3回会培 (1930 年) か開かれ山田はそれにも出席している。こうした

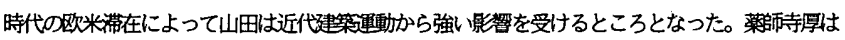
「30 才代の青年建等家であった山田さん欧米の現代建築をまのあたりに直接見て、非常な柬燩 を受けられたろうことは想像にかたくないっ（山田守策作品集开䘕会、『山田守建筑作品集小東 海大学出版会、昭和 42 年。）と山田の欧米の出㖘について叙述した。もちろん機能主義・合理主義 をそこで初めて知ったわけではないか、気質として多分に浪漫的なところをもち、分離原以来、表

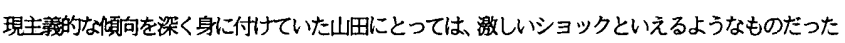
ようである。

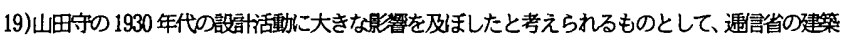

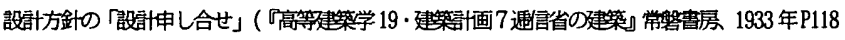




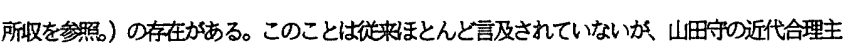

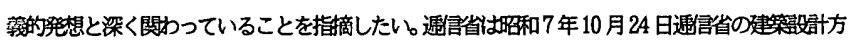

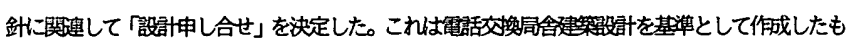

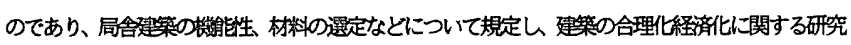

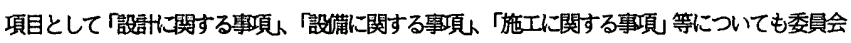

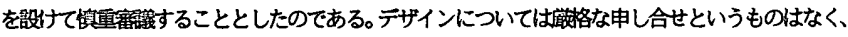

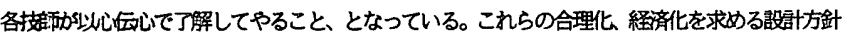

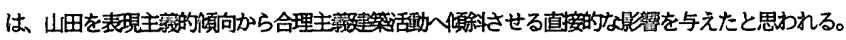

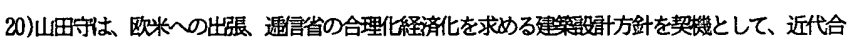

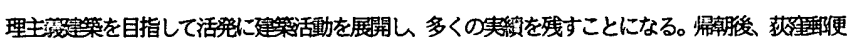

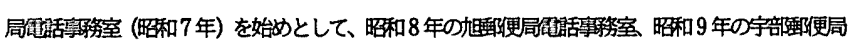

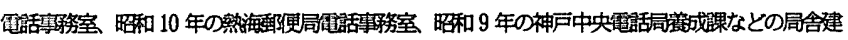

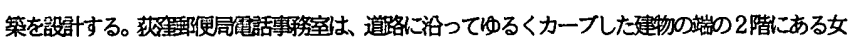
子更衣室の空汃、カンチレパーで突出した大きなガラス面の設計になっているのは当特の日本とし

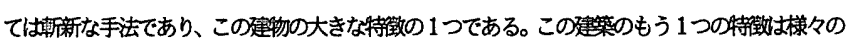

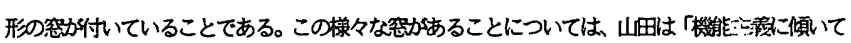

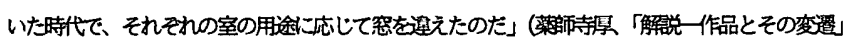

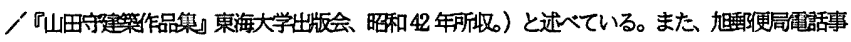

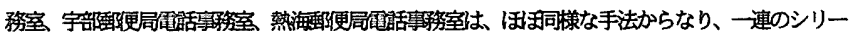

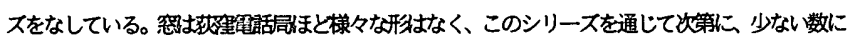

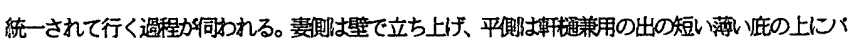
イフの手摺りか将いていること、曲線さ建物の角等に僅かに用いられているにすきない等 後の榶

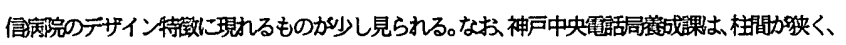

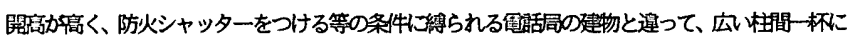

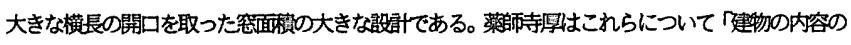
差加当然よことであるが、れはこの建物により軽快な感しを与えている。屋上の大きな 2 基

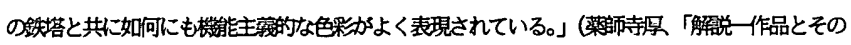

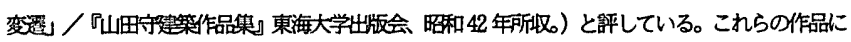

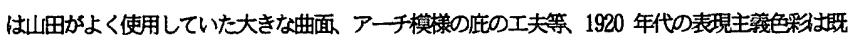

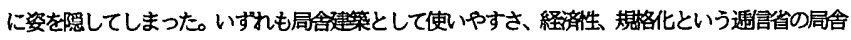

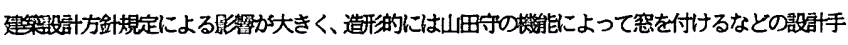

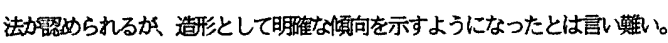

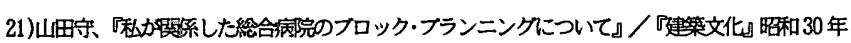
7 月号认所収。

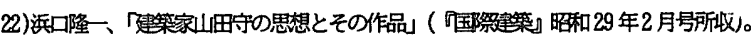

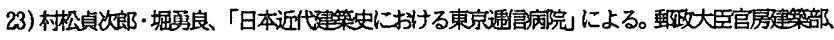

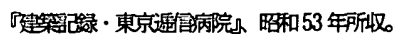

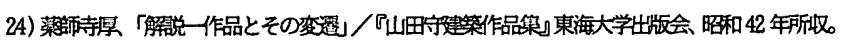

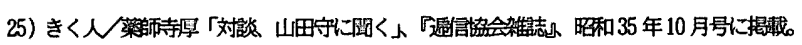

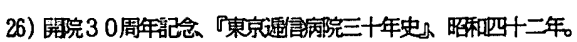

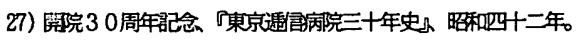

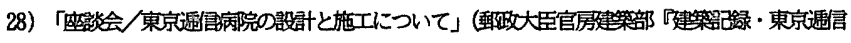

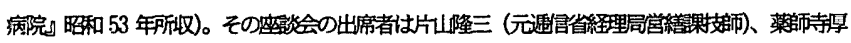

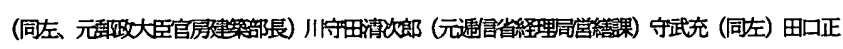

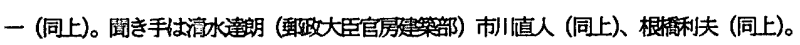

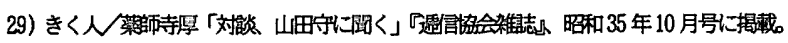

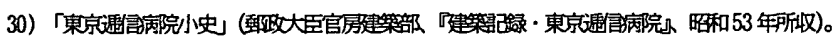

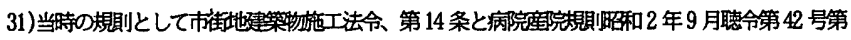

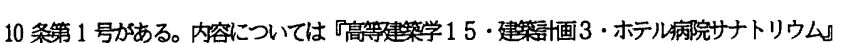
常箬䡒展 1933 年 第28編P37 を参照

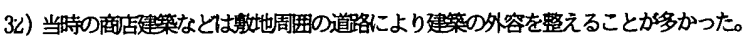

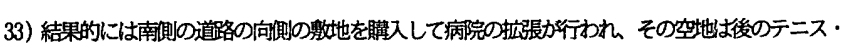
コートになっていた。

34)このようなヒストリーコリドアを配するアメリカ式フランについては、高松政婎著「病院」第

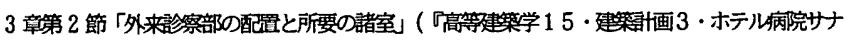

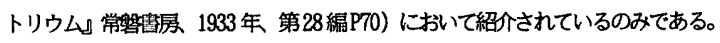
35)例えは，日本赤十字社大阪支部病院(1929 34 年)、京都帝国大学医学部拊属病院 (1931 年)、 满失大連因院本館 (1925 年) があるがこれらは日光澹室とティ・ルームを兼かた部洷であった。 36）当時病院建築の計画について詳細を紹介している、高松政婎著「病院」(䧚等建学 15 .

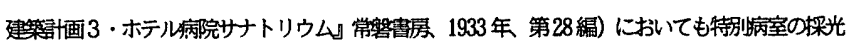
と日光浴との関係については述へているが単独の日光浴空の設置については言及されていない。

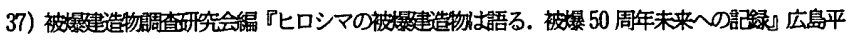
和婄念凟料館発行、P120〜121による。

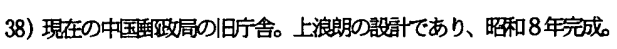

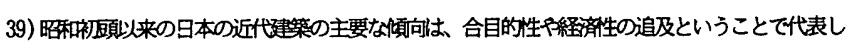
てよいのであるが、1935 年前後には、造形としてもかなり明雄な傎向を示すようになっていた。

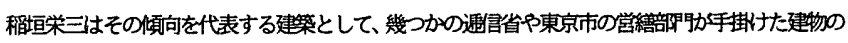

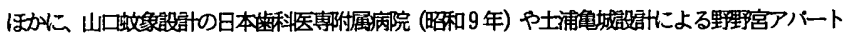

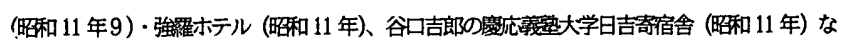

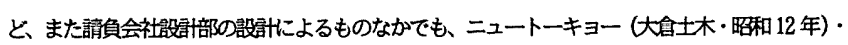
東日会领 (大合土木・昭和 13 年) などか挏し系列に属するだろうと述へている。(稻恒栄三『日 本の近代建筑 その成立過程] (下)』昭和54 年6月25 日発行。P345 を参照。

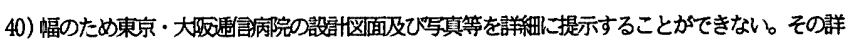

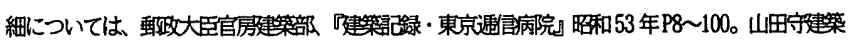

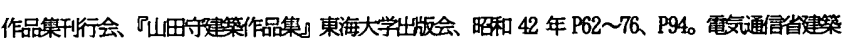

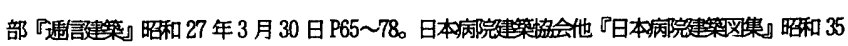
年3月1日P16〜21。などを参照すること。

41）当時の商店建築なとは舫地周井の道路により建築の外容を整えることが多かった。

42）この空地には 1962 年に大阪避言病院新館か建てられた (山田守の設計)。

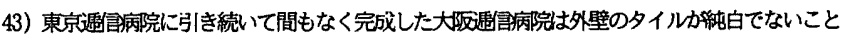

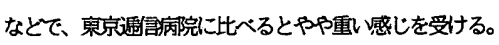

44）山田守『私か関係した総合病院のブロック・フランニングについ』／『建築文化』昭和 30 年 7月号に所收

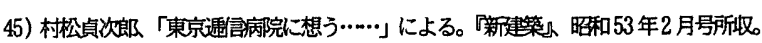

46)注28 と同し。

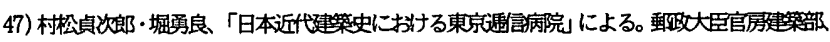

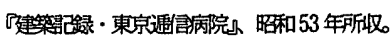

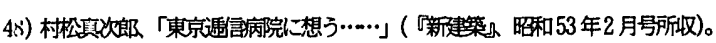

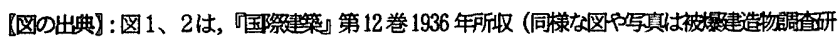

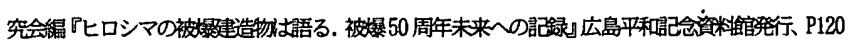

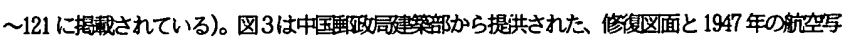

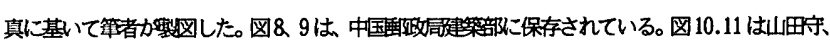

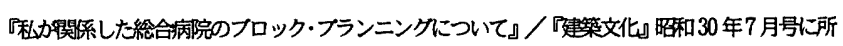

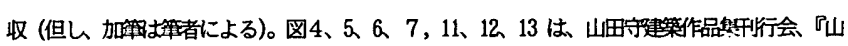
田守建築作品留、東海大学出版会、昭和 42 年所彼。 